\title{
65. Three Alleged Occurrences of Stegolophodon latidens (Clift) in Japan.
}

\author{
By Hisakatsu YABE, M.J.A.
}

(Comm. Nov. 13, 1950.)

There are three recorded cases of the occurrence of molars referred to Stegolophodon latidens (Clift) in Japan; the localities are :

1. Hanareyama, Kuzi-mati, Taga-gun, Ibaraki Prefecture.

2. Siogama near Sendai, Miyagi Prefecture.

3. Hunaoka-mati, Sibata-gun, Miyagi Prefecture ${ }^{1)}$.

\section{Hanareyama, Kuzi-mati, Taga-gun, Ibaraki Prefecture.}

Some palaeontological and stratigraphical notes of the Kuzi molars have recently been given by the writer in a short paper "Controversies Relating to the Kuzi Proboscidean Molars" in the last number of the Proceedings, Vol, XXVI. The two fragmental molars from this locality, once referred by S. Watase and T. Katô, H. Matsumoto and S. Tokunaga to Stegolophodon latidens, and later by F. Takai to Stegodon elephantoides (Clift), is now thought by the writer to represent probably a new species of Stegodon, which is far more advanced in the construction of molars than any species of Stegolophodon, but much less than Stegodon elephantoides. The Hanareyama sandstone with these molars belongs to the Taga beds; the fossil is not suitable for precise geological age-determination.

\section{Siogama near Sendai, Miyagi Prefecture.}

There are two molars recovered from the Tiganoura formation of Siogama, which originally belonged to one and the same skull. One of them, the upper molar, first acquired by the Institute of Geology and Palaeontology, Sendai (Reg. No. 7861), was described by Matsumoto") with his usual accuracy, who referred it to Stegolophodon latidens, then believing to be $\mathrm{Dp}^{4}$ or $\mathrm{M}^{1}$, and regarded

1) On p. 905 of his "Proboscidea", Vol. II, 1942, H.F. Osborn cited Kitayama, Sendai, as one of the localities of Stegolophodon latidens in Japan based on a letter from H. Matsumoto, dated Nov. 20, 1942. There is certainly some confusion; the Proboscidean molar found at Kitayama was described by Matsumoto under the name Trilophodon stndaicus, sp. nov., 1926. The present writer knows nothing at all about Stegodon remains from the locality.

2) H. Matsumoto : On Two Mastodonts and an Archetypal Stegodont of Japan. Sci. Rep. Tôhoku Imp. Univ., Ser. II (Geol.), Vol. X, No. 1, 1926, p. 10. 
it as less distinctly bunomastodontine and more distinctly stegodontine than Stegolophodon cautleyi (Lydekker). Osborn figured its mould on p. 845 of his "Proboscidea", Vol. II (Fig. 721) as "Referred Stegolophodon latidens, a very primitive stage", with an additional remark that "Referred. 41/2 ridge-crested Stegolophodon latidens (cautleyi?) from Siwogama..... Inner and superior aspects of a third right molar rM", with $4 \%$ + ridge-crests ".

The second specimen which the Institute fortunately procured many years latter (Reg. No. 72696) (Figs. 1-3) is a lower right third molar, $\mathrm{rM}_{3}$, of which a part of the anterior talon and the anneyed outer part of the first anterior ridge are broken. It is elongate oblong, longer than the riM", and gently narrowed posteriorly as well as anteriorly; along its inner border cingulum is more or less well developed. Ridge formula $1 / 2-5$; number of conelets 4-5. In the first specimen, $\mathrm{rM}^{3}$, the first anterior ridge shows a tendency to incline forwards, thus making the valley behind it wider than the succeeding ones; in this second specimen, $\mathrm{rM}_{3}$, the first anterior ridge is upright and the valley behind it is as wide as the succeeding ones.

\section{Hunaoka-mati, Sibata-gun, Miyagi Prefecture.}

During the second world war, an elephant skull was excavated from a hillside near Hunaoka-mati; unfortunately the greater part of the cranium was destroyed, but both jaws were safely procured. The lower jaw (Fig. 4) has $\mathbf{r M}_{1}, \mathbf{r M}_{2}, \mathbf{r M}_{3}, \mathbf{l M}_{2}, \mathbf{l M}_{3}$ in situ on the left and right mandibles; all teeth are badly damaged by natural deformation. The upper jaw (Fig. 5) has, besides a pair of incisors, $\mathrm{rM}^{2}, \mathrm{rM}^{3}, 1 \mathrm{M}^{2}, 1 \mathrm{M}^{3}$ in situ on maxillae, likewise in bad condition except for the posterior half of both M3.

Now $\mathrm{rM}^{3}$ and $\mathrm{rM}_{3}$ from Siogama compared with the corresponding ones from Hunaoka, they agree very well, except for some minor points, perhaps individual variations, and there is no doubt about their specific identity; their mother rocks are known to occupy the same stratigraphical position.

The ridge formula of M3 of the Siogama species is $\frac{{ }^{1 / 4}-4-1 / 2\left(\text { or }^{1} / 4-5\right)}{1 / 2-5}$ while that of Stegolophodon latidens is $\frac{1 / 4-5-1 / 2}{1 / 4-6-1 / 4}$. This difference is probably led Matsumoto to take the Siogama molar for either $\mathrm{Dp}^{4}$ or $\mathrm{M}^{1}$. In this respect, the former species better agrees with $S$. cautleyi, which has the ridge formula $0-4-1 / 2_{2}$.

The number of conelets in $M^{3}$ and $M_{8}$ of the Siogama species is 6 and 4 respectively, while that in M3 of Stegolophodon latidens is 4 and of $S$. cautleyi $4-5$. 


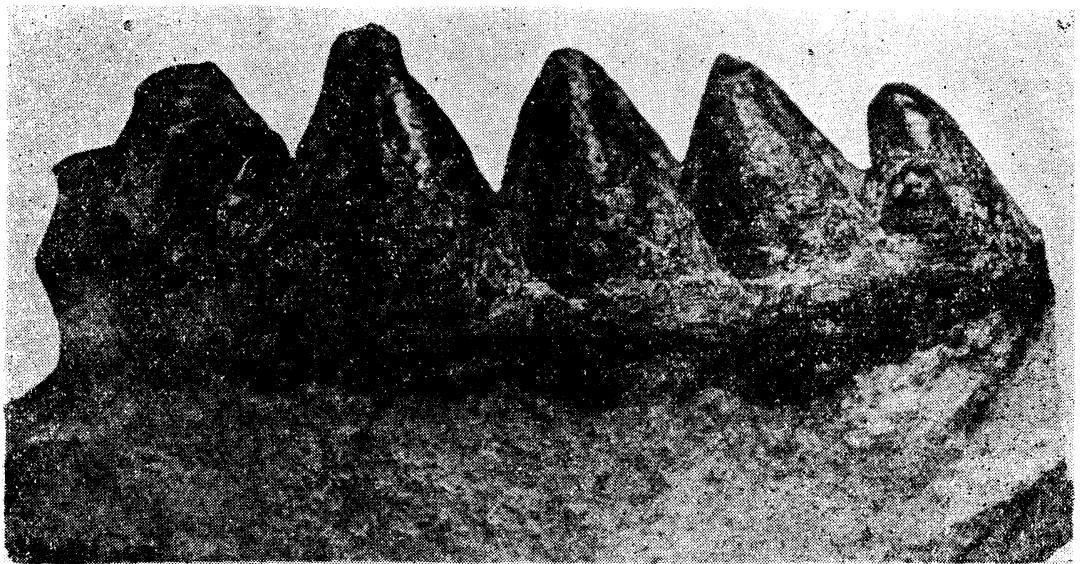

1

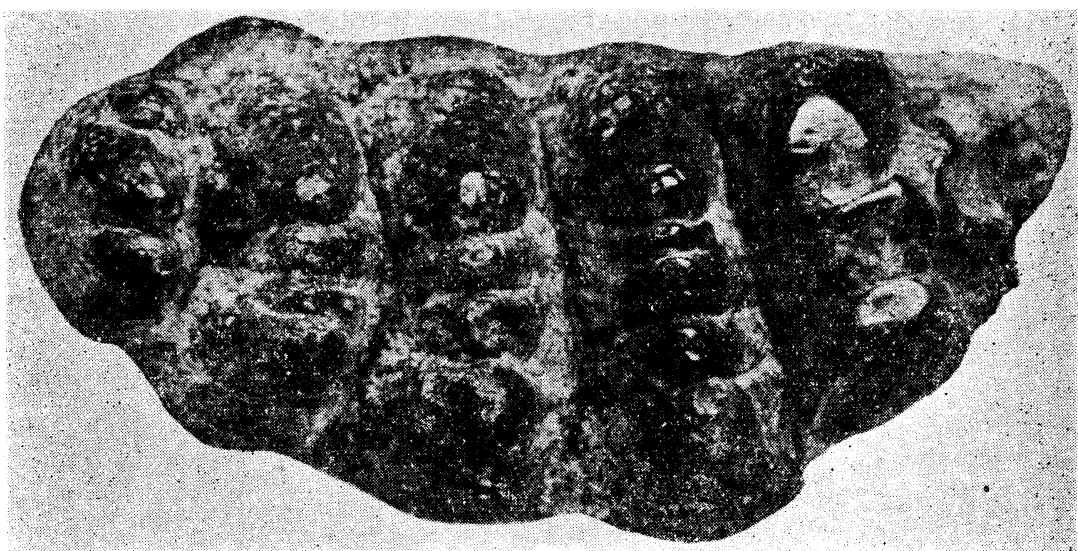

2

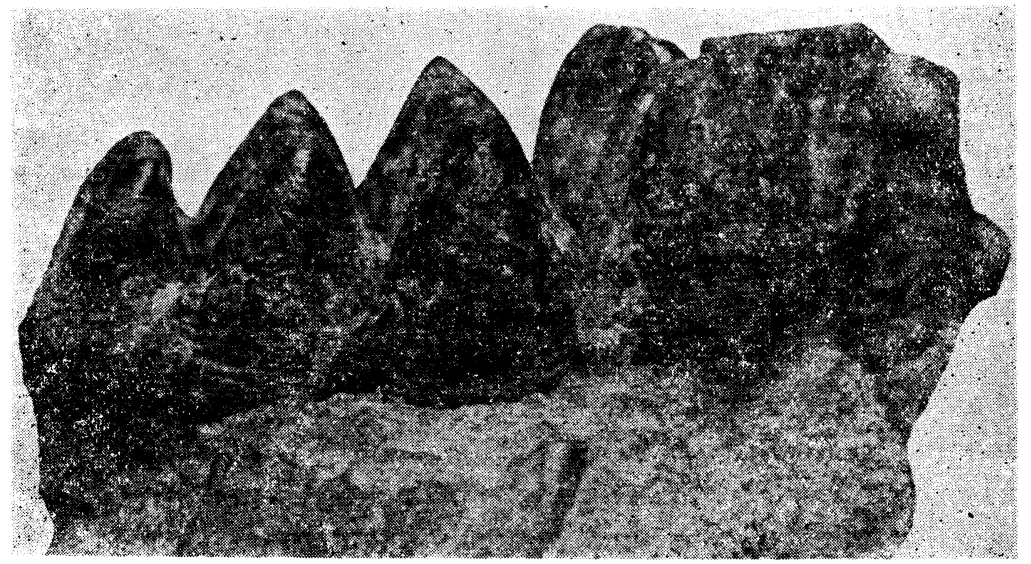

3

Figs. 1-3. Eostegodon pseudolatidens, gn. et sp. nov. from Siogama, near Sendai, three-fourth natural size. 1. internal view; 2. crown view; 3 . external view. 


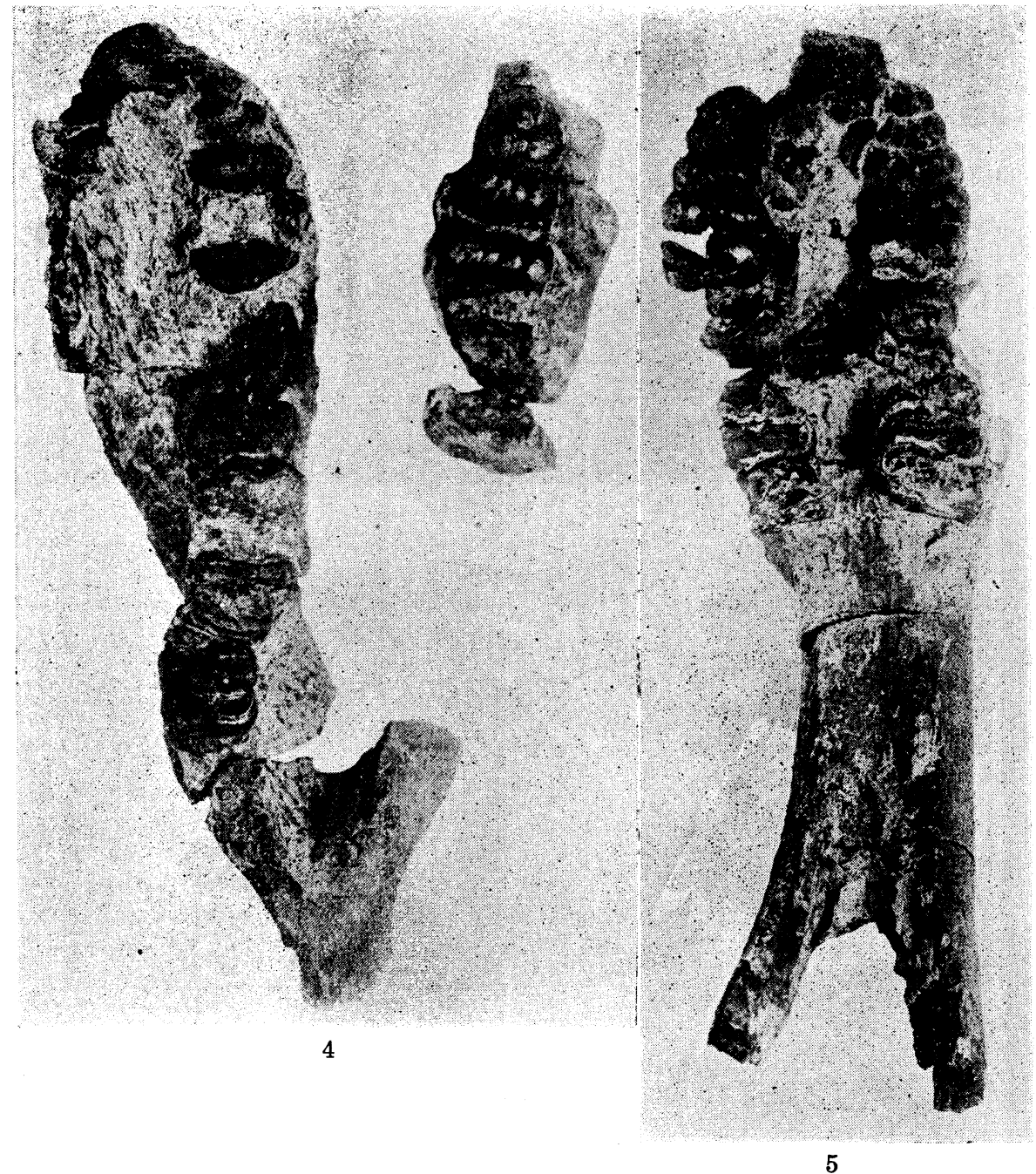

Figf. 4 and 5. Eostegodon pseudolatidens, gn. et sp. nov. from Hunaoka, Miyagi-gun, x 0.23. 4. lower jaw ; 5. upper jaw.

Hence the M3 of the Siogama species is less advanced in the number of ridges and more advanced in the number of conelets than S. latidens. Moreover, the ridges are relatively higher and narrower and have the conelets arranged more regularly linear in the Siogama species than in S. latidens and $S$. cautleyi; in these features the former more closely approaches Stegodon.

Some vestiges of the ancestral bunodontine features are still exhibited by anterior ridges of M3 of S. latidens and much more by those of $S$. cautleyi, while even the first anterior ridge of M3 is far less bunodontine in the Siogama species.

Furthermore, there is another difference between $\mathrm{M}^{3}$ of the Siogama species and that of $S$. latidens. In the latter it is stated 
that " three anterior ridges are closely compacted, closing the bottom of three valleys" "), while this is not the case in the former, as stated above, the first valley is rather wider than the succeeding ones.

It is therefore certain that the Siogama species is specifically distinct from Stegolophodon latidens and S. cautleyi from India and Burma. It is very probable that the former does not belong to the lineage, or group of lineages $S$. cautleyi progressus Osborn-cautleyilatidens-stegodontoides-lydekkeri Osborn. If the distinctive terms of bounolophodon-, stegolophodont- and stegodon stages in the evolutionary steps of the later Cenozoic Proboscidean molars is admitted, the stegolophodont stage was attained by Stegolophodon in the Pliocene time, but this same stage must be considered to have been passed through in a much earlier geological age by the Proboscideans belonging to the Stegodon lineage or group of lineages, because the oldest species of the latter genus, S. bombifrons Falconer and Cautley, "probably" from the Dhok Pathan horizon, Middle or Lower Pliocene, of the Siwalik, India, is already completed typical Stegodon, having $M^{*}$ with $91 / 2$ ridge-crest formula and $11+$ conelets. Its ancestral form with molars in the stegolophodont stage of molar evolution must be expected in a much older formatian. The Siogama species seems to fullfil this requirement, being found in the Tiganoura formation and especially somewhat below the Vicarya yokokamai and Desmostylus horizon, at Siogama, and in the Kanayama beds, contemporaneous with the Tukinoki plant beds, of Hunaoka, a terrestrial facies of the marine Lower Miocene Moniwa in the vicinity of Sendai. The fossil flora of the Tiganoura formation and that of the Tukinoki plant beds are also those characterizing the Japanese Lower Miocene.

The above mentioned accounts seems to justify the generic and specific separation of the "Stegolophodon latidens" from Siogama, and also of Hunaoka, from the true Stegolophodon latidens from India and Burma; the former should be hereafter distinguished under the name of Eostegodon pseudolatidens, gn. et sp. nov.

3) H.F. Osborn : 1. c.. p. 483. 